\title{
The Gendered Tertiary Education Transition: When Did It Take Place and What Are Some of the Possible Policy Implications?
}

\author{
Paul Callister, James Newell, Martin Perry and David Scott
}

\section{Introduction}

There has been much publicity in recent years about how girls are performing better than boys in many areas of schooling (Driessen, 2005). But in recent times New Zealand has also experienced a gender transition in tertiary educational enrolment and attainment, with, for the first time in our history, women participating in tertiary education at a significantly higher rate than men. ${ }^{1}$ This article sets out the magnitude and timing of the changes, highlights some of the reasons being put forward for them, and considers how the changes might influence a range of behaviour.

\section{Background}

Overall, the New Zealand population is considerably better qualified than it was 25 years ago. Using census data, Newell and Perry (2006) show that between 1981 and 2001 the proportion of New Zealand residents aged 15 years or older with no educational qualification halved, from $55 \%$ to $28 \%$, while those with a degree tripled, from $3.8 \%$ to $11.8 \%$. Newell and Perry caution that while this increase was impressive it was typical of changes taking place across the OECD. ${ }^{2}$

An expansion of the traditional tertiary education providers, namely universities, polytechnics and colleges

1 US data shows that in the period from the late 1890s through to the end of the 20th century there were times where there were slightly more women than men enrolled in tertiary education. However, more men than women graduated (Goldin and Katz, 2006). While similar long-term research has not been carried out in New Zealand, case studies indicate a comparable pattern. For example, in the case of enrolments at Victoria University, Barrowman (1999) shows that in 1920 women made up $42 \%$ of enrolments, but this had declined to around $25 \%$ by the 1950 s and 1960 s.

2 In fact, in 2001 New Zealand was still marginally behind the OECD country average when degree qualifications for 25 to 34 year olds were considered (Newell and Perry, 2006).

3 The Human Rights Commission has developed a modern apprenticeships strategy that aims to promote the inclusion of women (http://www.neon.org.nz/eeoissues/modernapprenticeships/ mastrategy/) of education, facilitated the initial growth in educational attainment of New Zealanders. In recent years, enrolments at non-traditional providers, including wānanga and private institutions, have augmented the expansion. All of these institutions have attracted New Zealanders but also foreign students. These trends are well known. Less well known are the gender imbalances in some specific areas of tertiary education.

The Human Rights Commission and the Ministry of Women's Affairs have pointed out that men dominate modern apprenticeships, with, in 2005, women holding only $8 \%$ of the more than 8,298 apprenticeships. ${ }^{3}$ In wider industry-based training as well men dominate. In 2004 there were 102,567 men involved in industrybased training, as opposed to 37,030 women. Less recognised, and perhaps equally important in the long term, is the overall shift in the gender composition of tertiary educational enrolments. There are now substantially more women than men enrolled in tertiary education. Tertiary educational enrolments include many of those studying via industry-based training, including modern apprenticeships, as a significant number of these students are enrolled in courses at polytechnics or other institutions. In 2000 there were just over 41,000 more women enrolled than men, but by 2004 this had increased to over 75,000 (Table 1 ). In overall numbers this imbalance dwarfs by an order of ten the excess of men in modern apprenticeships.

Not all enrolments result in qualifications, but qualification data support the overall picture of a major gender shift having taken place in tertiary education. The 2001 Census of Population and Dwellings shows that across the whole population aged 15 and older there were still marginally more men than women with a non-degree post-secondary qualification $(21.2 \%$ versus $19.7 \%$ ), as well as more men than women with a degree (12.4\% versus $11.2 \%)$. However, if only younger age groups are considered there are more women 
Table 1: Enrolments in tertiary education from 2000 to 2004, all age groups but excluding foreign students

\begin{tabular}{|c|c|c|c|c|c|}
\hline & 2000 & 2001 & 2002 & 2003 & 2004 \\
\hline Male & 144,101 & 158,054 & 171,568 & 200,888 & 219,284 \\
\hline Female & 185,508 & 208,405 & 240,696 & 269,117 & 294,439 \\
\hline Total & 329,609 & 366,459 & 412,264 & 470,005 & 513,723 \\
\hline
\end{tabular}

Source: Ministry of Education (2006)

Note: Enrolments and actual student numbers do not match as some students are enrolled in more than one course or institution.

than men with degrees or non-degree post-secondary qualifications. In 2001, in the 25-29 age group 20.8\% of women had attained a degree versus $17.2 \%$ of men. The transition has already taken place for Mäori and Pacific people. For example, 5.2\% of all Mäori women in 2001 had earned a degree, as opposed to $4.3 \%$ of Māori men.

Qualification trends are influenced by both inward and outward migration. Given that the 'best and brightest' tend to be the most mobile internationally, the balance of well-educated New Zealanders leaving and well-educated migrants arriving in New Zealand needs to be considered as well as participation in local education institutions. When the data are restricted to New Zealand-born residents the same pattern of an increasing number of well-educated young women relative to men emerges. For example, Newell and Perry's cohort analysis shows that in the 1951-56 to 1961-66 birth cohorts men were more likely to have earned degree qualifications. In later birth cohorts the rate at which women earn degrees outpaces men. The changes are particularly strong for the 1971-76 and 1976-81 birth cohorts. For example, of those women born in the period 1976-1981, and who were aged 20-24 in 2001, $14.1 \%$ had earned a degree. In contrast, for men in the same cohort $8.8 \%$ had earned a degree (Figure 1).

Annual enrolment data provide a more precise indication of when the tertiary education transition commenced than the five-yearly census. Focusing on those under the age of 30, an indication of likely future trends in educational attainment can be given, unaffected by any differential rate at which older persons re-engage with education. On this basis, the education transition can be dated to the late 1990s (Figure 2).

Figure 2 includes certificates through to postgraduate degrees. When educational enrolments are considered by level of education, additional important patterns emerge. The ratio of women to men in the mid-1990s shown in Table 3 indicates that there were considerably more men than women undertaking certificate courses. However, by 2004 there were $7 \%$ more women under 30 enrolled in this type of course. Of note also is the

Figure 1

\section{Percentage of NZ-born male and female residents with a degree aged 15 and 34, based on 1981 to 2001 census data}

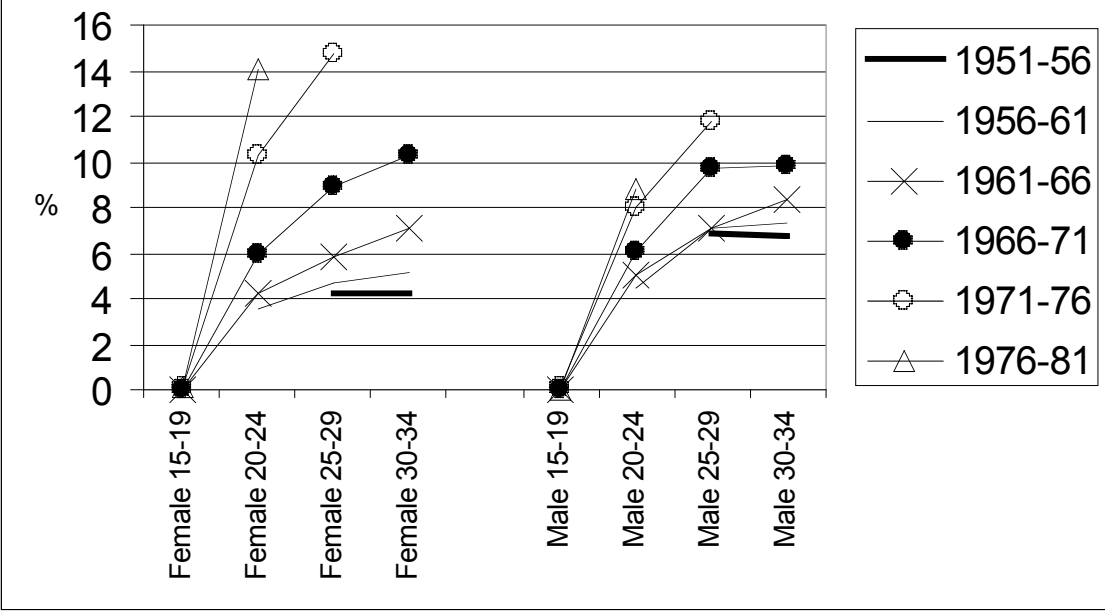


Figure 2

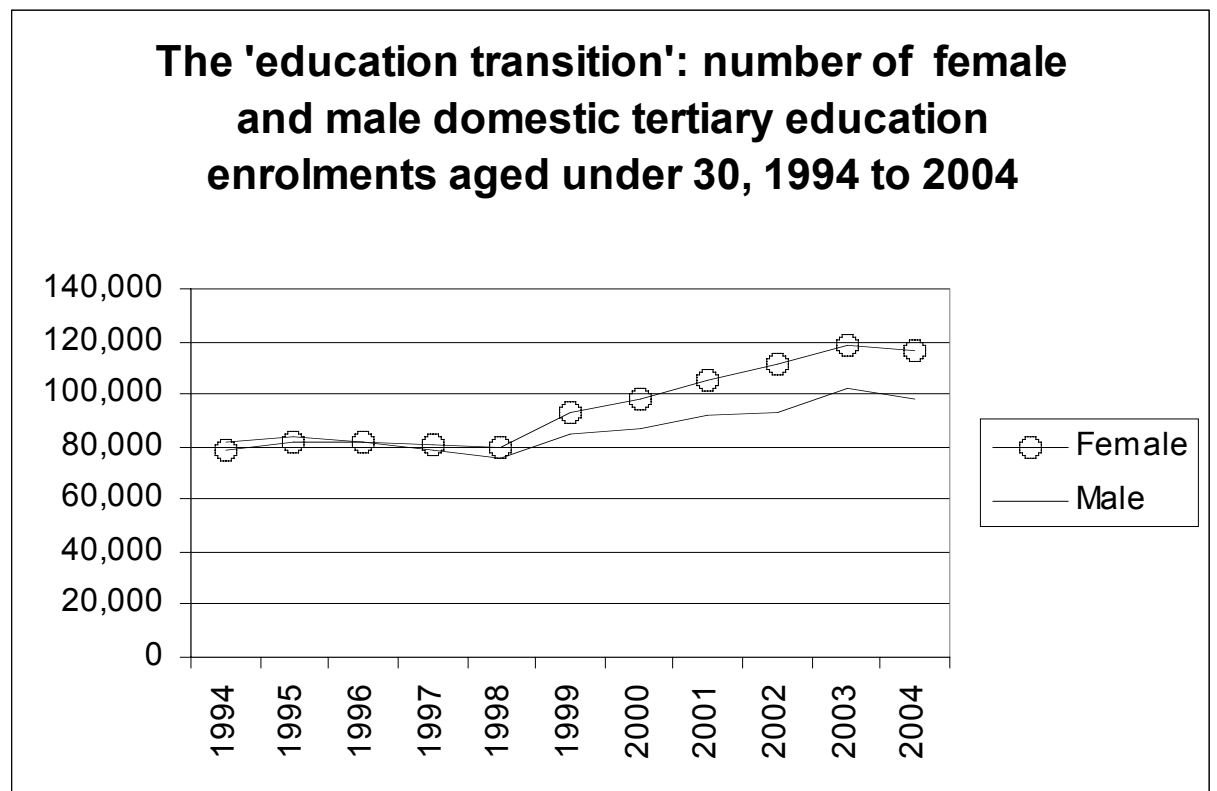

Note: In this figure and subsequent figures and tables that show enrolments from 1994, data prior to 1999 excludes enrolments in private tertiary education providers. Given that the numbers in these institutions prior to 1999 were very small, this exclusion does not change the overall trends.

Source: Ministry of Education (2006)

ratio of bachelor's degree enrolments. In 1994 there were $13 \%$ more young women enrolled in degrees, but by 2004 this had increased to $32 \%$. While total numbers are relatively low, there has also been a major shift in postgraduate enrolments, with, by $2004,42 \%$ more women under 30 enrolled than men. This is primarily due to an increase in numbers of women undertaking such study, while male enrolments have remained relatively stable (Table 2).

Table 2: Number of female and male enrolments in tertiary education for those under $\mathbf{3 0}$ years of age, domestic students only, 1994-2004

\begin{tabular}{|llllllllll|}
\hline & \multicolumn{2}{c}{ Certificate } & \multicolumn{2}{c}{ Diploma } & \multicolumn{2}{c}{ Bachelor's } & \multicolumn{2}{c|}{ Postgraduate } \\
\hline & Female & Male & Female & Male & Female & Male & Female & Male \\
1994 & 25,015 & 33,544 & 16,690 & 15,191 & 35,854 & 31,828 & 4,381 & 4,759 \\
1995 & 27,232 & 35,651 & 15,125 & 14,114 & 37,732 & 32,766 & 4,801 & 4,973 \\
1996 & 25,995 & 34,016 & 14,754 & 13,313 & 39,134 & 32,587 & 5,377 & 5,349 \\
1997 & 23,348 & 30,006 & 14,110 & 12,425 & 41,044 & 33,712 & 5,361 & 5,144 \\
1998 & 22,869 & 27,573 & 11,653 & 11,255 & 43,511 & 34,944 & 5,585 & 5,070 \\
1999 & 32,492 & 35,403 & 13,398 & 11,198 & 45,441 & 36,071 & 5,791 & 5,018 \\
2000 & 36,809 & 38,164 & 13,828 & 12,389 & 46,206 & 36,137 & 5,811 & 4,628 \\
2001 & 43,497 & 42,253 & 13,926 & 12,393 & 46,873 & 36,495 & 5,955 & 4,383 \\
2002 & 48,236 & 45,192 & 14,082 & 12,855 & 48,644 & 37,026 & 6,182 & 4,561 \\
2003 & 49,307 & 45,886 & 13,804 & 12,321 & 49,809 & 38,048 & 6,499 & 4,796 \\
2004 & 53,217 & 49,513 & 13,861 & 11,416 & 50,584 & 38,310 & 6,872 & 4,845 \\
\hline
\end{tabular}

Source: Ministry of Education (2006) 
Table 3: Ratio of female to male enrolments in tertiary education for those under 30 years of age, domestic students only, 1994-2004

\begin{tabular}{|c|l|c|c|c|}
\hline \multicolumn{2}{|c|}{ Certificate } & Diploma & Bachelor's & Postgraduate \\
\hline 1994 & 0.75 & 1.10 & 1.13 & 0.92 \\
1995 & 0.76 & 1.07 & 1.15 & 0.97 \\
1996 & 0.76 & 1.11 & 1.20 & 1.01 \\
1997 & 0.78 & 1.14 & 1.22 & 1.04 \\
1998 & 0.83 & 1.04 & 1.25 & 1.10 \\
1999 & 0.92 & 1.20 & 1.26 & 1.15 \\
2000 & 0.96 & 1.12 & 1.28 & 1.26 \\
2001 & 1.03 & 1.12 & 1.28 & 1.36 \\
2002 & 1.07 & 1.10 & 1.31 & 1.36 \\
2003 & 1.07 & 1.12 & 1.31 & 1.36 \\
2004 & 1.07 & 1.21 & 1.32 & 1.42 \\
\hline
\end{tabular}

Source: Ministry of Education (2006)

Within these changes are some important ethnic differences. Table 4 restricts the time period to 20002004. In terms of total tertiary enrolments for domestic students under 30 years of age in 2004, the gender ratios range from a low of $6 \%$ more Asian women than Asian men through to a high of $66 \%$ more Māori women than Māori men. These ethnic differences show up in all levels of qualification. In enrolments for bachelor's degrees, for example, the ratios of women to men within the Māori ethnic group are particularly extreme. In 1994 there were 21\% more Māori women under 30 years of age enrolled for a bachelor's degree, and by 2004 this had lifted to 77\%. But in 2004 the ratios for Pacific people and Europeans were also very much in favour of women.

\section{Institutional differences}

Are there institutional differences in the sex ratios of enrolments? Looking at gender imbalances for domestic students under 30 years of age by institutional types, of the eight universities only Lincoln and Canterbury had more men enrolled than women in 2004. The newest university, the Auckland University of Technology, had the highest proportion of women, at $60 \%$ of its students. Some of the differences will reflect gendered subject choices, with, for example, Lincoln University specialising in agricultural and horticultural courses, while Canterbury University has a large engineering school. Overall, in 2004 there were 26\% more women than men aged under 30 enrolled in universities
Table 4: Ratio of female to male enrolments for those under 30 years of age in each main ethnic group, domestic students only, 2000-2004

\begin{tabular}{|llllll|}
\hline & 2000 & 2001 & 2002 & 2003 & 2004 \\
\hline Asian & 1.02 & 1.04 & 1.03 & 1.03 & 1.06 \\
European & 1.11 & 1.11 & 1.10 & 1.11 & 1.12 \\
Māori & 1.29 & 1.50 & 1.67 & 1.67 & 1.66 \\
Other & 1.03 & 1.06 & 1.08 & 1.23 & 1.19 \\
Pasifika & 1.24 & 1.30 & 1.35 & 1.40 & 1.45 \\
Total & 1.13 & 1.15 & 1.17 & 1.17 & 1.18 \\
Unknown & 1.10 & 1.12 & 1.16 & 1.20 & 1.23 \\
\hline
\end{tabular}

Source: Ministry of Education

Ethnicity is based on total counts, so some people will be counted more than once.

The gender balance of individual polytechnics is more mixed. Again, this is likely to reflect subject specialisation, but also whether study can be carried out extramurally. For example, reflecting its agricultural courses, Telford Rural Polytechnic had few women enrolled, whereas the Open Polytechnic had over twice as many women enrolled as men in the under 30 age group. Reflecting the imbalances in trades training in favour of men overall, in 2004 there were $13 \%$ more men than women aged under 30 enrolled in polytechnics.

Teacher training is undertaken by a number of institutions, including colleges of education that have merged into universities. According to Ministry of Education data, by 2004 there were only two separate colleges of education. Reflecting a pattern of more female than male teachers in early childhood education and care, primary schools and secondary schools, these colleges have for a number of years had a greater number of young women than men enrolled. Overall, in 2004 there were 3.7 times as many young women enrolled as men.

Wānanga are a relatively new type of tertiary education provider. In 2004 Māori comprised 60\% of those enrolled in wānanga under 30 years of age. In all three wānanga there were more young women enrolled than men in 2004. The highest ratio was in Te Wānanga O Aotearoa, with nearly three times as many women than men. In contrast to other institutions, where it is Māori who have the highest ratios of young women to men 
enrolled, across the wānanga in total in 2004 it was amongst Europeans that the ratio of females to males was the highest.

Finally, recent decades have seen the emergence of many private providers. Taking these as a group, there were just under $40 \%$ more young women enrolled in these institutions than men in 2004.

\section{Field of study differences}

In commenting on the higher overall numbers of women in tertiary education, McGregor and Gray (2003, p.9) state that female areas of study are concentrated in relatively few areas. Certainly, enrolment data show that there are some areas where women are underrepresented, but they do not support this view of women being concentrated in only a few fields of study. Figure 3 shows total enrolments across all age groups, and includes foreign students, and is an update on the 2002 data used by McGregor and Gray. It shows only three broad areas of study in which, in 2004, men were enrolled in greater numbers than women. These are architecture and building, agriculture and environmental studies, and engineering and related technologies, fields of study with much smaller numbers enrolled overall than the larger areas such as commerce or society and culture.
When a finer level of field of study is used, there are some areas where women dominate, such as nursing, midwifery and teacher training, and areas where men dominate, such as automotive engineering and technology.

Table 5 again restricts the data to those under 30 and excludes foreign students. It also only includes those undertaking degree-level or higher study. There were two areas of study that were male-dominated in 2004, engineering and computing; and a further three where men significantly outnumbered women: architecture, town planning and resource management; mathematics; and religion and theology. In the areas of natural and applied sciences and sport and recreation there were slightly more men enrolled than women. In 11 out of the 19 study areas there were more women enrolled than men. Again, within these data are some finer field of study differences. For example, in the medical and health area at the degree or higher level in 2004 there were considerably more women enrolled in nursing, midwifery and radiography courses, but in the traditional male areas of study of audiology, dentistry, medicine and surgery, and optometry there were also more women than men. While there are certainly some areas of study where either men or women are concentrated, these fields of study data do not support the view that women are concentrated in just a few areas of tertiary study.

\section{Figure 3}

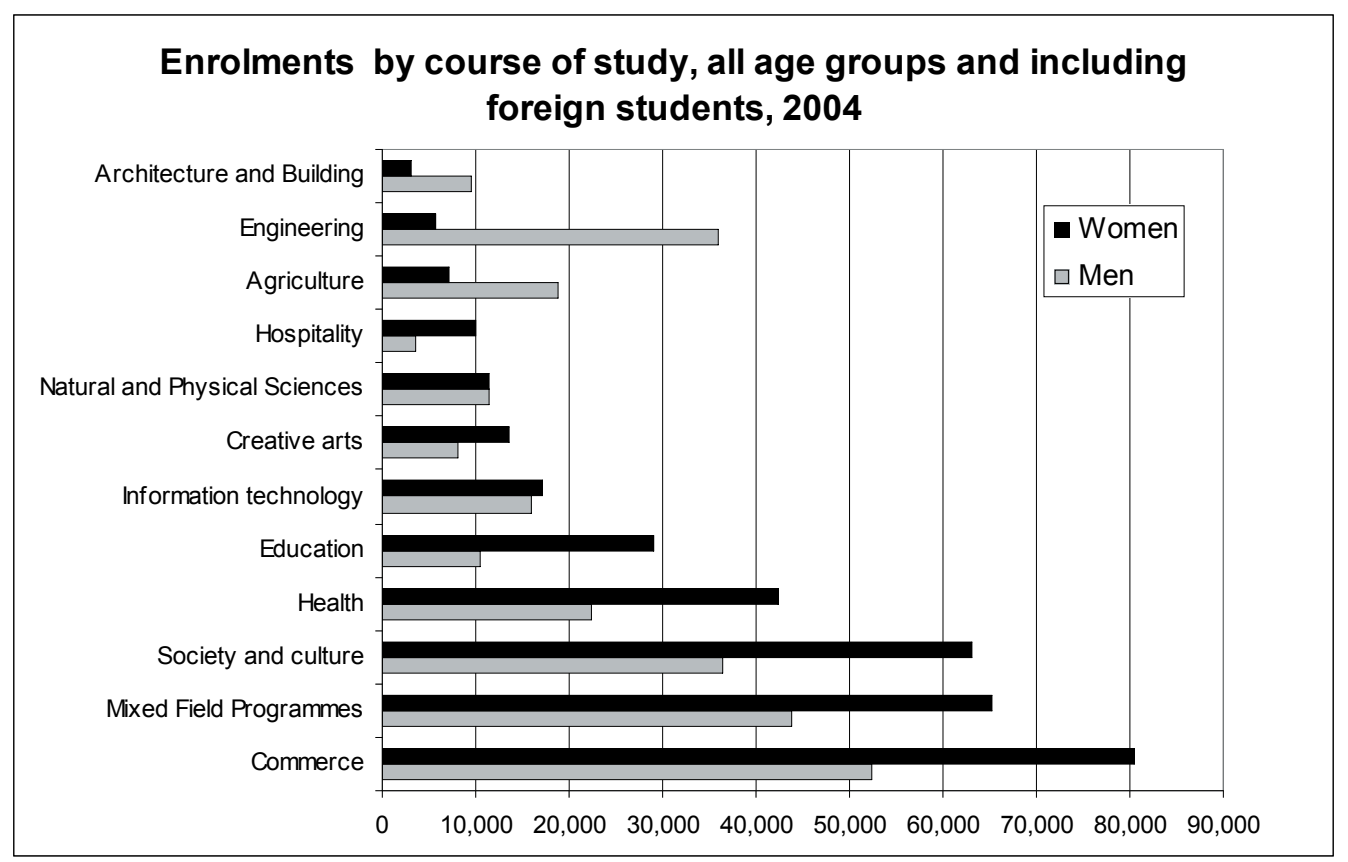

Source: Ministry of Education (2006). Note: 'Mixed field programmes' consist mainly of shorter courses in areas such as employment skills, literacy and numeracy, and life skills. However, while not a major component, this category also includes most doctoral studies. 
Table 5: Main fields of study in 2004, degreeand higher-level enrolments for women and men under $\mathbf{3 0}$ years of age and excluding foreign students

\begin{tabular}{|l|rrr|}
\hline \multicolumn{3}{|c|}{ Female } & $\begin{array}{r}\text { Male } \\
\text { Ratio of } \\
\text { women } \\
\text { to men }\end{array}$ \\
\hline $\begin{array}{l}\text { Agriculture, forestry, } \\
\text { fishing }\end{array}$ & 755 & 711 & 1.06 \\
Architecture, town & & & \\
planning, resource & 794 & 1,041 & 0.76 \\
management & & & \\
Art, music, handicrafts & 2,335 & 1,404 & 1.66 \\
Commercial \& business & 9,536 & 9,493 & 1.00 \\
Computing & 316 & 1,365 & 0.23 \\
Education & 5,543 & 1,311 & 4.23 \\
Engineering & 1,653 & 4,818 & 0.34 \\
General programmes & 1,536 & 1,281 & 1.20 \\
Humanities & 10,640 & 5,737 & 1.85 \\
Industrial trades \& crafts & 157 & 20 & 7.85 \\
Law & 3,932 & 2,367 & 1.66 \\
Mass communications & 720 & 244 & 2.95 \\
Mathematics & 13 & 17 & 0.76 \\
Medical \& health & 6,466 & 1,886 & 3.43 \\
Natural \& applied & 7,064 & 7,401 & 0.95 \\
sciences & & & \\
Religion \& theology & 69 & 91 & 0.76 \\
Service trades & 117 & 83 & 1.41 \\
Social, behavioural, & 1,732 & 512 & 3.38 \\
communication skills & & & \\
Sport and recreation & 926 & 998 & 0.93 \\
\hline
\end{tabular}

Source: Ministry of Education (2006)

\section{Why have the changes taken place?}

New Zealand is not the only country experiencing these changes, but it is among a small group of countries, including the United States, where the shifts have been particularly marked (Freeman, 2004). In the US context, Buchmann and DiPrete (2006) suggest that understanding both the causes and consequences of the growing gender disparity is a very important area for researchers and policy makers. Yet, despite this significance, little research has been carried out. They suggest that the US literature on gender inequalities in education still focuses primarily on female disadvantage, with, for example, concerns about the few areas where women are under-represented, such as engineering. This seems to be the situation in New Zealand as well. In addition, in both New Zealand and the US there continues to be a greater focus on gender imbalances among senior university staff, still markedly in favour of men, than in the make-up of the student body (Curtis and Phibbs, 2006).

It is perhaps not surprising that in New Zealand policy circles gender analysis focuses on female disadvantage, and that when a group of men are slipping behind this is neither highlighted nor researched. For example, the Ministry of Women's Affairs (1996, p.3) states that gender analysis:

- examines the differences in women's and men's lives, including those which lead to social and economic inequity for women, and applies this understanding to policy development and service delivery;

- is concerned with the underlying causes of these inequities;

- aims to achieve positive change for women.

While supposedly coming from a more gender-neutral background, the Families Commission has recently published a report entitled Methodologies for analysing the impact of public policy on families (True, 2005). Of relevance to female advantage in education, the cover of this report shows a mother helping her daughter with homework while her son appears to lie listless on the couch. Within the report, in a section on gender analysis the author notes that among other goals gender analysis 'highlights the practical needs and the strategic interests of women in the context of societal gender inequality' (p.32).

Given the focus on female disadvantage amongst policy makers and advisers, and, potentially connected with this focus, the paucity of both national and international research on the changing gender balance in education, understanding of the drivers of change currently relies heavily on theory. Drawing on a mix of theoretical and analytical work by Buchmann and DiPrete (2006), Dee (2006), DiPrete and Buchmann (2006) and Goldin and Katz (2006), current theories include that: 
- the schooling system has become feminised, in terms of both curriculum and teaching staff, which assists a greater proportion of girls to move on to tertiary education;

- more boys are being raised by mothers, without good male role models present in the family;

- new courses being developed by tertiary education providers tend to be in 'female dominated' subjects;

- women have seen better gains than men in earnings and other material benefits from their participation in higher education;

- women are genetically 'brighter' than men but have historically been held back by discrimination within the family, within schools and in the wider society;

- boys have slower social development and more serious behavioural problems than girls, so fewer advance to tertiary education;

- the increase in the age at first marriage has enabled women to invest more time in education;

- more effective birth-control methods have helped women invest in education and their careers. ${ }^{4}$

Tertiary institutions in New Zealand have also been encouraging women to enrol, and often their promotional literature has reflected this. For example, Massey University's 'Welcome to Massey University' web page for future students in August 2005 featured six women and two men. While the ratios were not as high on the other universities' welcome pages, overall more women were portrayed than men. ${ }^{5}$

One of the theories put forward as to why women are gaining higher education is that through such education they gain better earnings. This is, of course, a complex issue. While on average those with a degree or higher qualification earn more than those people who have earned their qualifications through schemes such as modern apprenticeships, where it is men who still dominate, with current shortages of trades workers in New Zealand, males opting for some trade occupations may, at least in the short term, be considerably better off than many of those women gaining a non-trade degree or postgraduate qualification.

As the empirical literature builds up, it is unlikely that there will be one main cause found for the change in educational participation and attainment by women relative to men, and some of the current theories may find little support.

\section{Longer-term implications of the changes}

The rising female advantage in college completion is an important topic of study both in its own right, as a rare example of a reversal of a once persistent pattern of stratification, and because of its potential impacts on labor markets, marriage markets, family formation, and other arenas. (Buchmann and DiPrete, 2006, p.3)

Buchmann and DiPrete set out a number of areas where the changes could have an impact. These include wage gaps, labour force participation, and other labour market outcomes; and trends in educational assortative mating, such as women marrying down educationally, delaying marriage or not forming couples. These changes, in turn, may have an impact on parenting decisions. The authors note that, in the US context, the gender gap is causing some concern among college administrators, as it is potentially detrimental to campus diversity. They also suggest that some university admissions officers are now considering issues of affirmative action for male applicants. ${ }^{6}$

The full effects of these changes may not be apparent for a number of decades. But some initial New Zealand data are available, and it is possible to speculate on what might be some of the effects. First, it is clear that rising educational outcomes for women has, overall, been a very positive trend. But it is possible that leaving a

4 In the longer term, the shifting of training into the tertiary sector will also have had some effect on the trends. For example, nursing education moved from hospitals to polytechnics, and then, in part, to universities. However, this took place in the 1970s and 1980s so is not a cause of the recent trends.

5 http://futurestudents.massey.ac.nz/. At this time Auckland University had a 3:1 ratio of women to men on a similar web page (http://www. auckland.ac.nz/uoa/for/prospective/home.cfm); Waikato University also a ratio of $3: 1$ (http://www.waikato.ac.nz/student/future.shtm); Victoria one woman and one man and a mixed crowd scene (http://www.vuw.ac.nz/home/prospective_students/index.html); Canterbury University and the Auckland Institute of Technology both had a $4: 1$ ratio of women to men (http://www.canterbury.ac.nz/ prospectivestudents.shtml; www.aut.ac.nz/students/); and Otago one man and one woman (http://www.otago.ac.nz/prospectivestudents/ index.php) (all accessed 2 August 2005).

6 Affirmative action is always a very difficult issue. If we knew for certain that differences in the numbers of men and women enrolled in particular courses was due to discrimination, there may be a case for having quotas in these areas. However, if such evidence is not available we should not automatically assume differences in enrolments show discrimination at work and that, as a result, affirmative action policies are appropriate. 
group of men behind will have some negative outcomes. If New Zealand is to become a high income, high employment society, with, for example, greater parity in wages with Australia, there will have to be increases in productivity. Given the links between education and productivity, further improvements in educational participation and performance at both school and tertiary levels are essential. Understanding why some groups of men, particularly Māori and Pacific men, have seen a deterioration in their relative education participation rates will assist with the development of more effective interventions to lift levels of performance not only in education but also in the labour market. The Human Rights Commission's concern with male dominance in modern apprenticeship participation, as expressed by McGregor and Gray (2003), takes on another light when the larger gender imbalance in tertiary education completions is considered. 'Recruiting from only "half" the population will not serve New Zealand well,' they state (p.2); but when it comes to wider tertiary qualifications it is now the male half that is being under-recruited. This suggests that policy makers should have some concern about recent trends in educational enrolment and attainment by young men relative to young women.

The direct labour market implications of the changes in education are difficult to predict. Employers will be recruiting from a larger pool of well-educated women and, in theory, this should result in an increase in the longer term in the proportion of women holding managerial and professional positions. However, these outcomes will be influenced by a range of factors, including the choices the women themselves make about career versus family roles, how employers and the wider society support women as well as men to integrate work and family obligations, and how, in the light of the changes in educational participation and attainment, men change their own expectations of work-life balance.

Not unconnected with labour market decisions, changing patterns of education can influence marriage and fertility choices. They may also influence household income inequality through changes in marriage choices. International research suggests that gaining higher levels of education, and the increased earning potential associated with better education, allows women to search longer for a suitable partner. Employment not only subsidises the marital search process, but it potentially reduces the economic rationale for marriage. Well-educated women are particularly likely to set higher standards for partner selection. When women start to become better educated than men, trying to maintain a pattern of 'marrying up' educationally will inevitably result in a decline in partnering for women. Alternatively, women may lower their relative educational expectations. Examples of marrying down educationally have always existed in New Zealand: for example, female school teachers or nurses marrying farmers without formal qualifications. This pattern may become far more common in the future. Census data through to 2001 suggest that already both these outcomes are becoming more widespread in New Zealand (Callister, 2006).

Mare and Schwartz (2006) argue that who marries whom has implications for the formation of families, the extent of inequality among families and individuals, and intergenerational inequality. Their research shows that over the past 40 years in the US the similarity of husbands' and wives' educational attainments has increased markedly. They note that although rising inequality among households may be a consequence of increasing spousal resemblance in terms of education, due in part to the strong increase in female educational attainment, increasing income inequality among individuals may itself be a cause of trends in educational assortative mating. In the US, as in New Zealand, increased earnings inequality for individuals has, in part, been an outcome of a rise in the number of people returning to education (O'Dea, 2000). This increases the incentives to either 'marry up' or, at least, not 'marry down'.

All these outcomes may in turn influence fertility decisions. Fertility may be increased through specialisation of roles if women are 'marrying up' and are encouraged to downgrade career success. On the other hand, if there is a shortage of well-educated men to partner well-educated women, there may be greater pressure on women to be 'breadwinners' rather than 'caregivers'. Equally, where couples are both well educated there are strong incentives for both to be breadwinners. Fertility may reduce unless the men that women are marrying have strong caregiving ideals, caregiving is strongly supported by the state through policies such as independent rights to paid parental leave for fathers (Callister and Galtry, 2006), or care outside the home is better supported, such as through low-cost child care. 
Finally, the changes in education may even influence patterns of ethnic intermarriage. For example, welleducated Māori and Pacific women are far more likely to have a partner outside their ethnic group than those with lower levels of education (Callister, Didham and Potter, 2005). In part this is likely to reflect the genderbased educational imbalances within these groups. If education increasingly plays a more important role in partner choice than ethnicity, as seems to be the situation in most industrialised countries, we can expect more 'outmarriage' by Māori and Pacific women. The changes in educational participation by Māori and Pacific women are also likely to have some impact on Māori and Pacific organisations. If, for example, Māori wish to have well-educated Māori lead iwi development, it will increasingly be young women rather than young men they will need to turn to.

\section{Conclusion}

The educational disparity between women and men within tertiary education, now in favour of women, is a relatively new, but very significant, change within society. Yet despite the magnitude of the change, policy makers currently seem somewhat oblivious to this shift. As one consequence, little is known in New Zealand about why this quite significant change has taken place and the possible long-term implications in areas such as the labour market and family form and function. We therefore suggest that New Zealand policy makers need to place this topic on their research agendas.

\section{Acknowledgement}

This research was prompted by data generated by an exploratory project on changing sex ratios in $\mathrm{New}$ Zealand funded by the Department of Labour (Callister, Bedford and Didham, 2006).

\section{References}

Barrowman, R. (1999) Victoria University of Wellington, 1899-1999: a history, Wellington: Victoria University Press

Buchmann, C. and T. DiPrete (2006) 'The growing female advantage in college completion: the role of family background and academic achievement', American Sociological Review, forthcoming

Callister, P. (2006) 'The potential effect of changes in sex ratios on the "marriage market", fertility and employment: a review of theory and evidence', working paper, Wellington: Department of Labour

Callister, P., R. Didham and D. Potter (2005) 'Ethnic Intermarriage in New Zealand', working paper, September, Wellington: Statistics New Zealand

Callister, P., R. Bedford and R. Didham (2006) 'Globalisation, gendered migration and labour markets', working paper, Wellington: Department of Labour

Callister, P. and J. Galtry (2006) 'Paid parental leave in New Zealand: a short history and future policy options', Policy Quarterly, 2 (1), pp.38-46

Curtis, B. and S. Phibbs (2006) 'Body politics within the academy: gender and the PBRF', paper presented at a symposium on the evaluation of the PBRF, Victoria University of Wellington

Dee, T. S. (2006) 'Teachers and the gender gaps in student achievement', NBER Working Paper No. 11660, revised March 2006.

DiPrete, T. and C. Buchmann (2006) 'Gender-specific trends in the value of education and the emerging gender gap in college completion', Demography, 43 (1), pp.1-24

Dougherty, I. (1999) Bricklayers and Mortarboards: a history of New Zealand polytechnics and institutes of technology, Palmerston North: Dunmore Press and Historical Branch, Department of Internal Affairs

Driessen, J. (2005) 'Trends in boys' education in New Zealand', in S. Birks (ed.), Proceedings: men's issues summits 2005, issues paper 5, Palmerston North: Centre for Public Policy Evaluation, Massey University, pp.12-18

Freeman, C.E. (2004) Trends in Educational Equity of Girls \& Women: 2004, NCES 2005-016, US Department of Education, National Center for Education Statistics, Washington, DC: US Government Printing Office

Goldin, C. and L.F. Katz (2006) 'The homecoming of American college women: the reversal of the college gender gap', Journal of Economic Perspectives, forthcoming

Mare, R.D. and C.R. Schwartz (2006) 'Income inequality and educational assortative mating in the 
United States: accounting for trends from 1940 to 2003', paper presented at the Annual Population Association of America meeting, Los Angeles, 30 March-1 April

McGregor, J. and L. Gray (2003) 'Modern apprenticeships: training for the boys? An equal employment opportunities discussion paper for the Human Rights Commission', http://www.neon.org. nz/documents/

Ministry of Women's Affairs (1996) 'The full picture: guidelines for gender analysis', http://mwa.govt.nz/ gender-analysis

Newell, J. and M. Perry (2006) Trends in the contribution of tertiary education to the accumulation of educational capital in New Zealand: 1981 to 2001, report prepared for the Ministry of Education, Wellington: Monitoring and Evaluation Research Associates Ltd

O'Dea, D. (2000) 'The changes in New Zealand's income distribution', working paper 00/13, Wellington: The Treasury

True, J. (2005) Methodologies for analysing the impact of public policy on families: a conceptual review, research report 5/05, Wellington: Families Commission
Paul Callister is a Senior Research Fellow in the Institute of Policy Studies at Victoria University of Wellington. His main research interests lie in the broad area of social policy and include issues relating to ethnicity, work-life balance, parental leave, migration patterns and labour market behaviour.

James Newell is an independent researcher and director of Monitoring and Evaluation Research Associates Ltd (MERA). The focus of his work is social research and its application to public sector service and infrastructure forecasting problems. Areas of research interest include measurement and forecasting of migration processes and demographic change, the changing nature of work, measurement of educational capital, occupational and industry demographic transformation and local development studies.

Martin Perry is a Senior Lecturer in the Department of Management and Enterprise Development, Massey University (Wellington), and was formerly a senior research analyst in the Labour Market Policy Group, Department of Labour. His research interests are in the area of local economic development and employment policy.

David Scott is a Senior Research Analyst in the Ministry of Education. His main research interests are in the area of tertiary education, in particular participation, attrition, completion, progression and pathways through and beyond tertiary study. 